\title{
Determinan Pemilihan Implan Pada Pasangan Usia Subur Di Kecamatan Medan Petisah
}

\section{Determinans of Selection of Implants in Fertile Age Pairs in Medan Petisah District}

\author{
Ayu Amalia Rahmi ${ }^{*}$, Ella Nurlaella Hadi ${ }^{1}$
}

${ }^{1}$ Departemen Pendidikan Kesehatan dan Ilmu Perilaku, Fakultas Kesehatan Masyarakat, Universitas Indonesia, Kampus UI Depok 16424, Indonesia

*Korespondensi penulis: amaliaayu54@gmail.com

\author{
Diterima (Recieved) \\ Direvisi (Revised) \\ : 19 Agustus 2020 \\ : 25 September 2020 \\ Diterima untuk diterbitkan (Accepted) : 24 Desember 2020
}

\begin{abstract}
ABSTRAK
Latar belakang. Penduduk Indonesia mengalami peningkatan dari 265.015 .300 orang pada tahun 2018 menjadi 268.074.600 orang pada tahun 2019. Pemerintah membuat program untuk mengintervensi masalah pertumbuhan penduduk yang tidak terkendali yaitu program keluarga berencana (KB). Metode Kontrasepsi Jangka Panjang (MKJP) dengan implan menjadi salah satu alat kontrasepsi unggulan dari BKKBN.

Tujuan. Penelitian ini bertujuan untuk melihat gambaran perilaku pemilihan implan dan determinannya.

Metode. Penelitian ini menggunakan metode kuantitatif dengan survei analitik cross sectional. Sampel 85 akseptor dari 560 dipilih dengan menggunakan simple random sampling. Pengumpulan data dilakukan melalui wawancara dengan menggunakan kuesioner. Data dianalisis secara univariat dan bivariat menggunakan uji chi-square.

Hasil. Sebanyak 11,8\% responden menggunakan metode implan. 71,8\% responden memiliki pengetahuan kurang, $65,9 \%$ responden bersikap negatif, $83,5 \%$ responden menilai peran petugas kesehatan masih kurang dan $67,1 \%$ responden yang tidak mendapatkan dukungan suami. Hasil analisis bivariat menunjukkan bahwa terdapat hubungan antara pengetahuan, peran petugas kesehatan, dan dukungan suami dengan pemilihan kontrasepsi implan, sedangkan sikap menunjukkan tidak ada hubungan dengan pemilihan konstrasepsi implan.

Kesimpulan. Ada hubungan antara variabel pengetahuan, peran tenaga kesehatan, dan dukungan suami dengan pemilihan Implan pada responden.
\end{abstract}

Kata Kunci: implan, KB, kontrasepsi

\section{ABSTRACT}

Background. Indonesia's population has increased from 265,015.3 million in 2018 to 268,074.6 million in 2019. The government has created a program to intervene in the problem of uncontrolled population growth, namely the family planning $(K B)$ program which is promoted and effective is the Long-Term Contraception Method (MKJP) with implants is one of the superior contraceptives of the BKKBN.

Objective. This study aimed to to see the selection of implants and their determinations.

Method. This study used a quantitative study with cross sectional analytic survey method. Sample of 85 acceptors from 560 were selected using simple random sampling. Data collection was carried out through interviews using a questionnaire. Data were analyzed by univariate and bivariate using chi-square test.

Results. Study found $11.8 \%$ of respondents used the implant method. $71.8 \%$ respondents have less knowledge, $65.9 \%$ of respondents have a negative attitude, $83.5 \%$ of respondents think that the role of health workers is still lacking, and $67.1 \%$ of respondents did not get support from their husbands. The results of the bivariate analysis showed that there was a relationship between knowledge, the role of health workers, and husband's support with the choice of implant contraception, while attitudes showed no relationship with the choice of implant contraception.

Conclusion. Knowledge variables, the role of health workers, and husband's support was related with the choice of implants in respondents.

Keywords: implants, $K B$, contraception

\section{LATAR BELAKANG}

Worldometers mencatat jumlah penduduk dunia pada 2019 mencapai 7,7 miliar jiwa. Angka tersebut tumbuh 1,08\% dari 2018 yang sebesar 7,6 miliar jiwa. Selama sepuluh tahun terakhir, jumlah penduduk dunia meningkat stabil dengan kisaran pertumbuhan 1-1,2\% per tahun. Sementara negara yang memiliki jumlah penduduk terbanyak adalah Tiongkok dengan jumlah 1,43 miliar jiwa, India sebanyak 1,37 miliar jiwa, Amerika Serikat (AS) sebanyak 329 juta jiwa, dan Indonesia sebanyak 270,6 juta jiwa. ${ }^{1}$ 
Jumlah penduduk yang meningkat sangat tinggi jika tidak diikuti dengan peningkatan kualitas sumber daya manusia maka akan menjadi bencana bagi Indonesia. Bencana kemiskinan, kriminalitas tinggi, dan masalah sosial lainnya akan muncul. Tidak hanya masalah sosial yang akan muncul, masalahmasalah lainnya akan bermunculan pula. $\mathrm{Mu}-$ lai dari masalah kerusakan lingkungan, pemanasan global, peningkatan kebutuhan pangan, energi dan air. Oleh karena itu, pemerintah membuat suatu program untuk mengintervensi masalah pertumbuhan penduduk yang tidak terkendali yaitu dengan program Keluarga Berencana (KB) bagi Pasangan Usia Subur. ${ }^{2}$

Pada tahun 2017, cakupan KB aktif secara nasional sebesar $63,6 \%$, dari 34 provinsi. Ada 15 provinsi yang cakupannya masih dibawah cakupan nasional. Provinsi D.I Yogyakarta merupakan provinsi dengan cakupan tertinggi sebesar $76 \%$ dan Provinsi Sumatera Utara masih berada dibawah cakupan nasional yaitu $52,8 \% .^{3}$

Ada 2.327.673 PUS di Provinsi Sumatera Utara. Jumlah peserta KB aktif ada $0,02 \%$ dan $0,08 \%$ peserta KB baru dari total PUS. Jenis metode kontrasepsi yang digunakan peserta KB aktif adalah suntik (30,69\% peserta), implan $(12,92 \%$ peserta), pil (6,97\% peserta), kondom (2,28\% peserta), IUD (1,25\% peserta), dan MOW+MOP (0,71\% peserta). Data tersebut menunjukkan penggunaan kontrasepsi non Metode Kontrasepsi Jangka Panjang atau MKJP berupa suntik merupakan metode yang paling banyak digunakan oleh PUS di Provinsi Sumatera Utara. ${ }^{4}$

Menurut profil Badan Pusat Statistik Kota Medan pencapaian akseptor KB aktif di 21 Kecamatan Kota Medan tahun 2015 sebanyak 333.535 akseptor. Dari jumlah tersebut hanya $6,23 \%$ alat kontrasepsi implan. Kecamatan Medan Labuhan memiliki pencapaian tertinggi sebesar $10,68 \%$ akseptor dan terendah di Kecamatan Medan Petisah sebesar 1,78\% akseptor. $^{4}$

Program kontrasepsi yang digalakkan dan efektif adalah implan yang merupakan salah satu alat kontrasepsi unggulan dari Badan Kependudukan dan Keluarga Berencana (BKKBN). ${ }^{2}$ Dengan dijadikannya implan sebagai alat kontrasepsi unggulan maka tanggal 1 November 2016 diperingati sebagai kegiatan Gebyar KB implan. Alat kontrasepsi implan memiliki efektivitas sampai 99\% dengan tingkat kegagalan hanya 1 dari 100 wanita yang menggunakannya atau kegagalan hanya mencapai $0,05 \% .^{2}$ Implan merupakan alat kontrasepsi yang praktis dan efektif. Dengan implan maka tidak ada lagi faktor lupa dan sangat cocok untuk wanita yang tidak bisa memperoleh asupan hormon esterogen tambahan. ${ }^{2}$ Kelebihan implan yaitu sifatnya jangka panjang yang tingkat kegagalannya lebih sedikit dibandingkan IUD atau dengan strerilisasi (tubektomi). Sementara alat KB berupa pil dan suntikan sifatnya jangka pendek dan kerap gagal, karena faktor lupa. ${ }^{5}$

Data Puskesmas Darussalam Kecamatan Medan Petisah menunjukkan jumlah peserta KB aktif sebanyak $16,84 \%$ peserta dari 3.325 PUS pada 2017. Metode kontrasepsi yang digunakan yaitu suntik $49,64 \%$ peserta, pil $38,39 \%$ peserta, IUD $6,60 \%$ peserta, MOW $2,5 \%$ peserta, kondom $1,78 \%$ peserta dan implan $1,07 \%$ peserta. Di wilayah kerja Puskesmas Darussalam jumlah peserta KB implan masih sedikit, hanya $1,07 \%$ dari 560 peserta KB aktif.

Rendahnya angka implan di wilayah kerja Puskesmas Darussalam dapat dipengaruhi oleh faktor internal antara lain rasa takut saat pema-sangan implan, merasa tidak cocok dengan kontrasepsi hormonal, dan tidak mendapatkan dukungan dari suami atau keluarga. Penyebab faktor eksternal yang mempengaruhi seperti lingkungan tetangga yang negatif terhadap implan, kurangnya informasi dari petugas kesehatan baik di puskesmas maupun kader kesehatan. Ikut atau tidaknya menjadi peserta KB dipengaruhi oleh tiga faktor yakni faktor predisposisi seperti pengetahuan, sikap, nilai kepercayaan, budaya; faktor pendukung seperti tersedia atau tidaknya fasilitas kesehatan; dan faktor pendorong seperti sikap, perilaku, keahlian, dan dukungan petugas. ${ }^{6}$

Penelitian Yuanti dan Maesaroh menunjukkan bahwa faktor-faktor yang berhubungan dengan pemilihan MKJP yaitu usia, paritas, pendidikan, pekerjaan, pengetahuan dan akses pelayanan KB. ${ }^{7}$ Penelitian di Kabupaten Ogan Ilir menunjukkan bahwa faktor-faktor yang berhubungan dengan pemilihan implan adalah sikap ibu mengenai 
implan dan peran suami, namun variabel pengetahuan tentang implant tingkat pendidikan dan pelayanan konseling KB tidak berhubungan dengan penggunaan implan. ${ }^{8}$

\section{METODE}

Penelitian ini menggunakan pendekatan penelitian kuantitatif dengan desain potong lintang. Data dianalisis secara univariat maupun bivariat menggunakan uji chi-square. Data dikumpulkan dengan cara wawancara door to door menggunakan kuisioner pada bulan Februari-Mei 2017. Pengumpulan data di wilayah kerja Puskesmas Darussalam Kecamatan Medan Petisah. Puskesmas Darussalam memiliki dua kelurahan yaitu Kelurahan Sei Sikambing D dan Sei Putih Barat.

Penentuan besar sampel sesuai rumus Lameshow sebagai berikut:

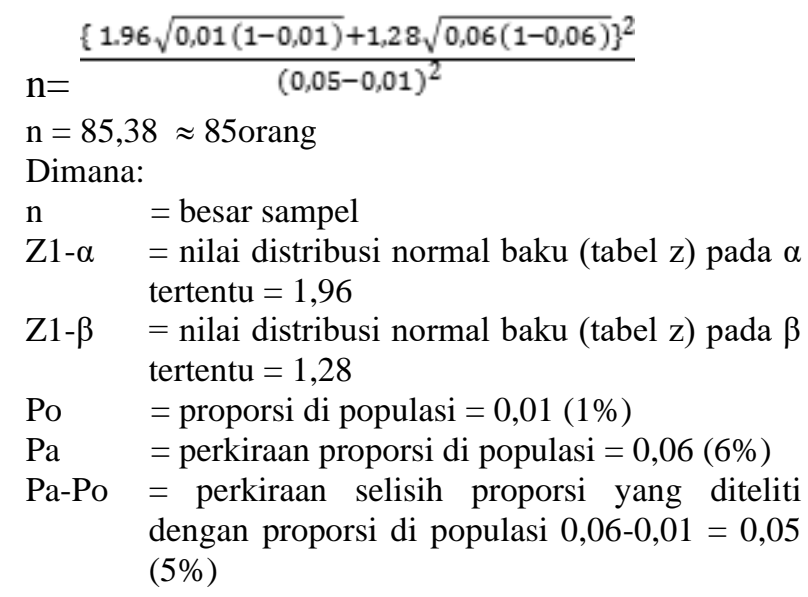

Populasi pada penelitian ini sebanyak 560 PUS yang menjadi peserta KB aktif di wilayah tersebut. Sampel penelitian sebanyak 85 PUS yaitu 45 PUS di Kelurahan Sei Sikambing D dan 40 PUS di Sei Putih Barat dipilih secara acak sederhana.

Tabel 1. Distribusi Responden Menurut Karakteristik Responden $(n=85)$

\begin{tabular}{|c|c|c|}
\hline Variabel Independen & $\mathbf{f}$ & Persentase \% \\
\hline \multicolumn{3}{|l|}{ Umur } \\
\hline Tidak Berisiko (20-35 tahun) & 54 & 63,5 \\
\hline $\begin{array}{l}\text { Berisiko }(<20 \text { tahun dan }>35 \\
\text { tahun) }\end{array}$ & 31 & 36,5 \\
\hline Jumlah Anak & 79 & 92,9 \\
\hline Tidak Berisiko ( $\leq 3$ anak) & 6 & 7,1 \\
\hline \multicolumn{3}{|l|}{ Berisiko (>3 anak) } \\
\hline Pemilihan Alat Kontrasepsi & 10 & 11,8 \\
\hline Implan & 4 & 4,7 \\
\hline IUD & 39 & 45,9 \\
\hline Pil & 28 & 32,9 \\
\hline Suntik & 4 & 4,7 \\
\hline \multicolumn{3}{|l|}{ Kondom } \\
\hline Pengetahuan PUS & 24 & 28,2 \\
\hline Baik & 61 & 71,8 \\
\hline \multicolumn{3}{|l|}{ Kurang } \\
\hline Sikap PUS & 29 & 34,1 \\
\hline Positif & 56 & 65,9 \\
\hline \multicolumn{3}{|l|}{ Negatif } \\
\hline Peran Petugas Puskesmas & 14 & 16,5 \\
\hline Baik & 71 & 83,5 \\
\hline \multicolumn{3}{|l|}{ Kurang } \\
\hline Dukungan Suami & 28 & 32,9 \\
\hline Mendukung & 57 & 67,1 \\
\hline Kurang mendukung & & \\
\hline
\end{tabular}




\section{HASIL}

Tabel 1 menunjukkan 63,5\% responden berada pada umur tidak berisiko yaitu 20-35 tahun) dengan rerata umur 32 tahun. Sebanyak $92,9 \%$ responden memiliki anak $\leq$ tiga orang dengan rata-rata dua orang anak, $45,9 \%$ responden memilih jenis kontrasepsi pil dan $11,8 \%$ responden memilih implan. Sebanyak $71,8 \%$ responden mempunyai pengetahuan kurang tentang implan dengan skor pengetahuan rata-rata 5 dan $65,9 \%$ responden memiliki sikap negatif terhadap implan dengan skor rata-rata sikap responden yaitu 26. Sebanyak $83,5 \%$ responden mengatakan bahwa peran petugas puskesmas masih kurang dalam memberikan informasi tentang implan dengan rata-rata skor yaitu 2 . Sebanyak $67,1 \%$ responden tidak mendapatkan dukungan dari suaminya untuk menggunakan implan dengan skor rata-rata 1.

Dari Tabel 2 diketahui bahwa proporsi pemilihan implan pada responden dengan pengetahuan baik tentang implan lebih tinggi dibandingkan responden dengan pengetahuan kurang. Terdapat hubungan bermakna antara pengetahuan responden dengan pemilihan alat kontrasepsi implan. Responden dengan pengetahuan baik tentang implan berpeluang untuk memilih implan 14 kali lebih tinggi dibanding mereka yang pengetahuannya kurang.

Proporsi responden dengan sikap positif terhadap pemilihan implan lebih tinggi dibandingkan proporsi responden dengan sikap negatif di mana $p=0,729(\mathrm{OR}=1,33,95 \%$ CI: 0,34-5,16). Tidak ada hubungan bermakna antara sikap dan pemilihan alat kontrasepsi implan.

Proporsi pemilihan implan pada responden yang menilai peran petugas puskesmas baik lebih tinggi dibanding dengan yang menilai peran petugas kesehatan kurang yaitu sebesar $100 \%$ dengan $\mathrm{p}=0,012$ $(\mathrm{OR}=1,67,95 \% \quad \mathrm{CI}: 1,38-2,01)$. Terdapat hubungan bermakna antara peran tenaga kesehatan dengan pemilihan alat kontrasepsi implan. Responden yang menilai peran petugas baik berpeluang untuk memilih implan hampir 2 kali lebih tinggi dibanding mereka yang menilai peran petugas kesehatan masih kurang.

Tabel 2. Distribusi Responden Menurut Pengetahuan, Sikap, Peran Petugas Kesehatan, Dukungan Suami dan Pemilihan Alat Kontrasepsi Implan

\begin{tabular}{|c|c|c|c|c|c|c|c|c|}
\hline \multirow{3}{*}{ Variabel Independen } & \multicolumn{4}{|c|}{ Pemilihan Alat Kontrasepsi } & \multirow{2}{*}{\multicolumn{2}{|c|}{ Total }} & \multirow{3}{*}{$p$-value } & \multirow{3}{*}{ OR (95\% CI) } \\
\hline & \multicolumn{2}{|c|}{ Implan } & \multicolumn{2}{|c|}{ Non Implan } & & & & \\
\hline & $\mathbf{n}$ & $\%$ & $\mathbf{n}$ & $\%$ & $\mathbf{n}$ & $\%$ & & \\
\hline \multicolumn{9}{|l|}{ Pengetahuan } \\
\hline Baik & 8 & 80,0 & 16 & 22,2 & 24 & 100 & \multirow[t]{2}{*}{0,001} & 14,0 \\
\hline Kurang & 2 & 20,0 & 56 & 77,8 & 58 & 100 & & $(2,69-72,61)$ \\
\hline \multicolumn{9}{|l|}{ Sikap } \\
\hline Positif & 6 & 60,0 & 50 & 66,7 & 56 & 100 & \multirow[t]{2}{*}{0,729} & 1,33 \\
\hline Negatif & 4 & 40,0 & 25 & 33,3 & 29 & 100 & & $(0,34-5,16)$ \\
\hline \multicolumn{9}{|l|}{ Peran Tenaga Kesehatan } \\
\hline Baik & 10 & 100,0 & 45 & 60,0 & 55 & 100 & \multirow[t]{2}{*}{0,012} & 1,67 \\
\hline Kurang & 0 & 0,0 & 30 & 40,0 & 30 & 100 & & $(1,38-2,01)$ \\
\hline \multicolumn{9}{|l|}{ Dukungan Suami } \\
\hline Mendukung & 10 & 100 & 0 & 0,0 & 10 & 100 & \multirow{2}{*}{0,0005} & \multirow[t]{2}{*}{$(-)$} \\
\hline Tidak mendukung & 0 & 0,0 & 75 & 88,2 & 75 & 100 & & \\
\hline
\end{tabular}




\section{PEMBAHASAN}

Dalam upaya untuk mewujudkan keluarga berkualitas, sasaran utamanya yaitu terkendalinya pertumbuhan penduduk dan meningkatnya jumlah keluarga kecil yang berkualitas, ditandai dengan meningkatnya penggunaan metode kontrasepsi yang rasional, efektif dan efesien (REE). Metode kontrasepsi yang memenuhi unsur efektif dan efesien adalah IUD, Metode Operasi Wanita (MOW), Metode Operasi Pria (MOP), dan implant. Efektif untuk mengatur jarak kehamilan dan biayanya lebih murah dengan sekali membayar pelayanan dapat digunakan dalam waktu yang panjang, sehingga disebut MKJP. ${ }^{9}$

Hasil penelitian pada MKJP diketahui bahwa kontrasepsi implan lebih banyak dipilih dibandingkan kontrasepsi IUD. Hasil tersebut menunjukkan dari empat variabel yang diduga sebagai determinan pemilihan implan ternyata hanya tiga variabel yang siginifikan berhu-bungan dengan pemilihan yaitu pengetahuan tentang implan, peran tenaga puskesmas, dan dukungan suami, sedangkan sikap responden terhadap pemilihan implan tidak berhubungan.

Penelitian ini menunjukkan pengetahuan tentang implan berhubungan dengan pemilihan implan, walaupun proporsi responden yang pengetahuannya kurang lebih besar dibanding mereka yang pengetahuannya baik. Pengetahuan yang sudah baik mencakup pengertian implan, tempat pemasangan implan, dan kapan implan dapat dipasang serta berapa lama pemakaian implan. Responden masih banyak yang tidak tahu tentang cara kerja implan, keuntungan pemasangan implan, efek samping pemasangan implan, kontraindikasi dan kapan waktu implan dapat dibuka. Penelitian lainnya menemukan penyebab rendahnya pengetahuan responden dikarenakan kurangnya informasi tentang implant dan kurangnya informasi dari tenaga kesehatan. ${ }^{10}$ Berdasarkan teori perilaku menguatkan penjabaran di atas bahwa perubahan perilaku yang tidak didasari dengan pengetahuan dan kesadaran maka tidak akan berlangsung lama. ${ }^{11}$ Menurut Elias ${ }^{12}$, hasil penelitian yang dilakukan di Ethiopia Selatan menunjukkan bahwa alasan utama yang dikeluhkan oleh wanita yang menikah untuk tidak menggunakan metode kontrasepsi implan yaitu ketakutan jika kontrasepsi implan dilepas $(54,5 \%)$, takut efek samping $(49,4 \%)$, keinginan untuk memiliki anak lebih banyak (48\%), didukung suami $(36,4 \%)$, takut akan kematian anak $(30,9 \%)$ dan kurang pengetahuan $(24,1 \%)$.

Penelitian lain memperlihatkan bahwa ada pengaruh penyuluhan kesehatan terhadap pe-ngetahuan Pasangan Usia Subur (PUS) dalam pemilihan kontrasepsi di Desa Kalama Darat Kecamatan Tamako Kepulauan Sangihe. ${ }^{13}$ Menurut Tibaijuka et al. ${ }^{14}$ mengatakan bahwa mereka yang lebih berpengetahuan tentang kontrasepsi lebih cenderung memiliki sikap positif terhadap metode jangka panjang dan lebih cenderung digunakan oleh mereka. Oleh karena itu, dapat disimpulkan bahwa pemilihan implan tidak dipengaruhi oleh pengetahuan responden tetapi oleh faktor eksternal yaitu kesadaran untuk menggunakan implant dan ketersediaan implan.

Hasil penelitian memperlihatkan bahwa sikap responden tidak berhubungan dengan pemilihan implan. Hal ini berbeda dengan temuan penelitian Marilia ${ }^{15}$ yang mengatakan bahwa ada hubungan antara responden yang mempunyai sikap positif terhadap pemilihan implan. Sesuai dengan yang dikemukakan oleh Azwar ${ }^{16}$ ada lima ciri sikap yaitu bukan dibawa sejak lahir melainkan dibentuk atau dipelajari sepanjang perkembangan dan dalam hubungan dengan objeknya, dapat berubahubah, tidak berdiri sendiri, objek itu merupakan sesuatu yang tertentu, dan sikap mempunyai segi-segi motivasi dan segi-segi perasaan. Penelitian lainnya menunjukkan bahwa sikap responden sangat berpengaruh terhadap alat kontrasepsi yang akan dipilih. Responden yang memiliki sikap yang baik terhadap sesuatu dapat dise-babkan oleh kepercayaan positif yang dimiliki responden, dan sebaliknya. Jika kepercayaan terhadap sesuatu bersifat negatif, maka akan menimbulkan sikap yang negatif pula. ${ }^{17}$ Oleh karena itu, dapat disimpulkan bahwa sikap positif responden mengenai implan akan berdampak terhadap pemilihan implan.

Dukungan tenaga kesehatan berhubungan dengan pemilihan implan. Responden menga- 
takan bahwa petugas kesehatan melakukan penyuluhan tentang implant dan menyarankan responden untuk memilih implan. Penelitian ini sejalan dengan penelitian yang dilakukan di Kecamatan Medan Labuhan bahwa ada hubungan peran tenaga kesehatan terhadap pemilihan implant. Sebagian besar responden memilih implan dikarenakan mendapatkan dukungan dari petugas kesehatan. ${ }^{18}$ Sesuai dengan teori Green ${ }^{19}$ bahwa salah satu faktor yang mempengaruhi PUS untuk me-milih alat kontrasepsi adalah peran tenaga kesehatan, seperti memberikan pelayanan konseling oleh pemberi pelayanan KB. Hal ini sejalan dengan hasil penelitian di Kecamatan Tegalsari Kabupaten Banyuwangi tahun 2015 di mana penggunaan implan terus mengalami peningkatan dari tahun ke tahun. Peningkatan tersebut dipengaruhi oleh peran para PLKB yang aktif memberikan pengarahan, informasi serta pendampingan. ${ }^{20}$ Penelitian lain menunjukkan ada hubungan antara peran tenaga kesehatan dalam memberikan konseling $\mathrm{KB}$ dengan penggunaan alat kontrasepsi pada wanita pasangan usia subur di puskesmas Rafae. ${ }^{21}$ Dapat disimpulkan bahwa informasi tentang implan dan pelayanan konseling oleh tenaga kesehatan perlu dilakukan untuk membantu responden memperoleh gambaran tentang implan lalu menghasilkan keputusan yang tepat atas pilihannya. Namun keputusan dalam memilih implan akan kembali pada responden tersebut.

Hasil penelitian menunjukkan dukungan suami berhubungan dengan pemilihan implan. Penelitian ini sejalan dengan penelitian di Kabupaten Ogan Ilir yang menemukan adanya hubungan dukungan suami terhadap pemilihan implant. ${ }^{8}$ Berdasarkan teori Green bahwa perilaku ditentukan oleh salah satu faktor yaitu faktor pendorong seperti adanya dukungan dari keluarga. Dukungan suami merupakan satu faktor pendorong responden untuk memilih implant. ${ }^{22}$ Penelitian lainnya juga berpendapat yang sama bahwa sebagian besar responden yang berminat menggunakan Alat Kontrasepsi Implan adalah para akseptor KB yang mendapatkan dukungan dari suami. ${ }^{18}$ Dukungan suami merupakan salah satu variabel sosial budaya yang sangat berpengaruh terhadap pemakaian alat kontrasepsi bagi kaum wanita sebagai istri secara khusus dan di dalam keluarga secara umum. ${ }^{23} \mathrm{Bu}-$ daya yang menjadikan pria sebagai kepala keluarga masih banyak dianut sebagian pola keluarga di dunia. Preferensi suami terhadap fertilitas, pandangan dan pengetahuan-nya terhadap program KB akan sangat berpengaruh atas keputusan di dalam keluarga untuk menggunakan alat atau cara KB tertentu. Dalam beberapa penelitian, variabel penolakan atau persetujuan dari suami terbukti berpengaruh. ${ }^{24}$ Kurangnya dukungan suami terhadap pemilihan alat kontrasepsi implan karena suami tidak merasa peduli terhadap alat kontrasepsi tersebut. Suami merasa hal tersebut bukanlah urusannya, namun merupakan urusan isteri saja. Padahal dukungan suami sangat berperan dalam pemilihan implan.

\section{KESIMPULAN}

Proporsi pengetahuan responden lebih besar pada kategori kurang, sikap responden lebih banyak dengan kategori negatif, lebih banyak peran petugas kesehatan dengan kategori kurang, dan lebih banyak responden yang tidak mendapatkan dukungan suami. Terdapat hubungan antara variabel pengetahuan, peran tenaga kesehatan, dan dukungan suami dengan pemilihan implan pada responden. Tidak ada hubungan bermakna antara sikap responden dengan pemilihan implan pada responden.

\section{SARAN}

Kepada petugas kesehatan wilayah kerja Puskesmas Darussalam agar memberikan penyuluhan dan promosi lebih sering kepada masyarakat, terutama pasangan usia subur. Materi promosi kesehatan perlu mencakup alat kontrasepsi implan agar pengetahuan dan sikap masyarakat khususnya PUS dalam meningkatkan pemilihan alat kontrasepsi implan menjadi lebih baik, efisien, dan efektif.

\section{UCAPAN TERIMA KASIH}

Penulis mengucapkan terima kasih kepada Kepala Puskesmas Kecamatan Darussalam Kecamatan Medan Petisah beserta jajarannya yang telah mengizinkan dan membantu penelitian ini. 


\section{DAFTAR REFERENSI}

1. Jumlah Penduduk Dunia pada 2019 Capai 7,7 Miliar Jiwa | Databoks [Internet]. [cited 2020 Feb 22]. Available from: https://databoks.katadata.co.id/datapublish/20 19/09/10/jumlah-penduduk-dunia-pada-2019capai-77-miliar-jiwa

2. Kementrian Kesehatan RI. Pusat Data dan Informasi Kementrian Kesehatan RI. 2014.

3. (BKKBN) BK dan KB. Peran Bkkbn Di Balik Gerakan Penanggulangan Stunting. Jurnal Keluarga. 2018;(1):44.

4. Statistik Indonesia 2015. Badan Pusat Statistik 2015. 2015;

5. Anita Lontaan, Kusmiyati RD. Faktor Faktor Yang Berhubungan Dengan Pemilihan Kontrasepsi Pasangan Usia Subur Di Puskesmas Damau Kabupaten Talaud. JIDAN Jurnal Ilmiah Bidan. 2017;2(1):480.

6. Green LW, Kreuter. Health Program Planning. An Educational Ecological Approach. New York: The MeGraw-HiII Companies. Inc; 2005.

7. Yuanti Y, Maesaroh M. Determinan Pemilihan Metode Kontrasepsi Jangka Panjang (Mkjp) Pada Pasangan Usia Subur. Jurnal Ilmiah Ilmu Kesehatan: Wawasan Kesehatan. 2019;5(2):154-61.

8. Imroni M, Fajar N, Febry F. the Factors Which Were Related With Implant Usage in Desa Parit Kecamatan Indralaya Utara Kabupaten Ogan Ilir. Jurnal Ilmu Kesehatan Masyarakat. 2010;1(1):73-9.

9. (BKKBN) BK dan KB. Rencana Strategis Badan Kependudukan dan Keluarga Berencana Nasional. In Jakarta; 2015.

10. Rohmawati E, Suprapti S, Damayanti FN. Perbedaan Pengetahuan Sebelum Dan Sesudah Penyuluhan Tentang Kontrasepsi Implan (Studi pada WUS di Rw IV Desa Wonolopo. Jurnal Kebidanan [Internet]. 2013; Available from: http://103.97.100. 145/index.php/jur_bid/article/view/554

11. Notoatmodjo S. Promosi Kesehatan dan Perilaku Kesehatan. Jakarta: Rineka Cipta; 2012.

12. Elias B, Hailemariam T. Implants Contraceptive Utilization and Factors Associated among Married Women in the Reproductive Age Group (18-49 Year) in Southern Ethiopia. Journal of Women $\mathrm{s}$ Health Care. 2015;04(07).

13. Kaseuntung C, Kundre R B. Pengaruh penyuluhan kesehatan terhadap pengetahuan wanita usia subur (WUS) dalam pemilihan kontrasepsi di Desa Kalama Darat
Kecamatan Tamako Kepulauan Sangihe. Journal Keperawatan. 2015;3.

14. Tibaijuka L, Odongo R, Welikhe E, Mukisa W, Kugonza L, Busingye I, et al. Factors influencing use of long-acting versus shortacting contraceptive methods among reproductive-age women in a resourcelimited setting. BMC Women's Health. 2017;17(1).

15. Gonçalves MJ, Suariyani NLP, Suryadhi NT. Hubungan Pengetahuan dan Sikap dengan Pemakaian Alat Kontrasepsi pada PUS di Puskesmas Comoro Dili Timor Leste. Public Health and Preventive Medicine Archive. 2014;2(1):39.

16. Azwar A. Metodologi Penelitian Kedokteran \& Kesehatan Masyarakat. Jakarta: Binarupa Aksara; 2005.

17. Setiasih S, Widjanarko B, Istiarti T. Analisis Faktor-faktor yang Mempengaruhi Pemilihan Metode Kontrasepsi Jangka Panjang (MKIP) pada Wanita Pasangan Usia Subur (PUS) di Kabupaten Kendal Tahun 2013. Jurnal Promosi Kesehatan Indonesia. 2016;11(2):32.

18. Tampubolon I, Tarigan J. Hubungan Pengetahuan, Dukungan Suami dan Petugas Kesehatan dengan Penggunaan Alat Kontrasepsi Bawah Kulit (AKBK) pada Pasangan Usia Subur di Lingkungan II Kelurahan Nelayan Indah Kecamatan Medan Labuhan. 2018;1(2).

19. Lawrence W. Green. Modifying and. Modifying and Developing Health Behavior. 1984;5:215.

20. Nuzula F, Widarini NP, Karmaya INM. Faktor-Faktor yang Berhubungan dengan Pemakaian Implan pada Wanita Kawin Usia Subur di Kabupaten Banyuwangi. Public Health and Preventive Medicine Archive. 2015;3(1):84.

21. Eurusia Ita Bria. Hubungan Peran Tenaga Kesehatan Dalam Memberikan Konseling $\mathrm{Kb}$ Dengan Penggunaan Alat Kontrasepsi Pada Wanita Pasangan Usia Subur Di Puskesmas Rafae Kabupaten Belu Nusa Tenggara Timur. 2014.

22. Notoatmodjo S. Ilmu Perilaku Kesehatan. Jakarta: Rineka Cipta; 2010. 249 p.

23. Hanum Z, Spautri I. Konseling dan Dukungan Suami dengan Minat Ibu dalam Pemakaian Kotrasepsi Implan. 2014;14(10):5-9.

24. Seulatan PP, Kelurga M, Bahagia K. Dalam Pemakaian Kontrasepsi Implan. 2014;14(10):5-9. 